\title{
Short communication: Feeding a rumen-degradable amino acid affects plasma thyroxine and triiodothyronine concentrations
}

\author{
K. M. Hultquist, ${ }^{1 *} \dagger$ J. A. Clapper, ${ }^{2}$ and D. P. Casper ${ }^{1}$ \\ ${ }^{1}$ Furst-McNess Company, 120 E. Clark Street, Freeport, IL 61032 \\ ${ }^{2}$ Department of Animal Science, South Dakota State University, Brookings 57006
}

\section{ABSTRACT}

Our previous published work demonstrated that feeding rumen-degradable valine to late-lactation dairy cows increased milk production compared with controlfed cows, with a response that was equivalent to that of recombinant bovine somatotropin. To further elucidate the response mechanism, we hypothesized that thyroxine (T4) and triiodothyronine (T3), which are important regulators of basal metabolism, may be involved. Previous short-term studies have demonstrated increased milk production when feeding iodinated casein. Eight multiparous Holstein dairy cows (255 \pm $26.4 \mathrm{~d}$ in milk) were blocked by milk yield $(34.1 \pm$ $8.25 \mathrm{~kg} / \mathrm{d}$ ) and randomly assigned to 1 of 4 treatments using a replicated $4 \times 4$ Latin square design with 21 -d periods $(7 \mathrm{~d}$ for dietary adaptation and $14 \mathrm{~d}$ for data collection). Treatments were control $(\mathrm{CON})$, a single injection of recombinant bovine somatotropin (rbST), and synthetic valine fed at 40 (V40) or 80 (V80) g/ cow per day. Cows were fed a total mixed ration with a distillers dried grains carrier fed at $113.4 \mathrm{~g} / \mathrm{d}$ containing no valine or added valine. Blood samples were collected twice during wk 2 and 3 of each period for $\mathrm{T} 3$ and T4 analysis. Concentrations of T4 $(3.28,3.90$, 3.98 , and $3.87 \mu \mathrm{g} / \mathrm{dL}$ for CON, rbST, V40, and V80, respectively) were increased for cows receiving $\mathrm{rbST}$, V40, and V80 compared with CON cows. Concentrations of T3 (125.7, 140.7, 148.8, and $139.7 \mathrm{ng} / \mathrm{dL})$ were increased for cows receiving rbST, V40, and V80 compared with CON cows, with cows receiving V40 having the highest T3 concentrations. In conclusion, feeding rumen-degradable valine increases plasma T4 and T3 concentrations, which would explain the mechanism leading to increased milk production.

Key words: dairy cow, milk production, thyroid, valine

Received January 2, 2019

Accepted March 27, 2019.

*Corresponding author: kayla.hultquist@kentww.com

†Current address: Kent Nutrition Group, 2905 Hwy 61 North, Muscatine, IA 52761.

\section{Short Communication}

It has been difficult to achieve consistent milk production responses when balancing rations for metabolizable AA on commercial dairy operations (D. P. Casper, personal communication). One of many concerns is that, when balancing for AA, feed formulation software packages give different rations because of different methods used to calculate AA requirements and supply (Yoder, 2015). One issue with AA balancing is the lack of knowledge on the quantity of dietary AA being metabolized by the rumen, the ruminal escape quantity, and the quantity absorbed across the intestinal wall (Kung and Rode, 1996). A meta-analysis by Zanton et al. (2014) cites research studies that have shown that increasing dietary AA has led to increased milk production, an important aspect for dairy producers, but also cites studies that have not demonstrated a response. In addition, nutrients and their metabolites can be metabolic modifiers (NRC, 1994; McGuffey, 2017). Therefore, the AA formulation might be changing the ration sufficiently to influence hormonal concentration or release.

Isoacids (isobutyric, 2-methyl butyric, and isovaleric acids) have been used in the past to enhance milk production of lactating dairy cows by increasing ruminal fiber digestion (Papas et al., 1984; Peirce-Sandner et al., 1985), but commercialization failed because of an unpleasant odor (National Center for Biotechnology Information, 2015). Liu et al. (2009) demonstrated that feeding isobutyrate (an isoacid) resulted in an $11 \%$ increase in blood growth hormone $(\mathbf{G H})$ concentrations. This observation suggests that feeding Val (which is ruminally metabolized to isobutyric acid) presents an opportunity to stimulate the release of natural GH from the anterior pituitary.

We previously demonstrated that feeding additional dietary synthetic Val to late-lactation dairy cows increased milk production comparably to responses observed with recombinant bST (Hultquist and Casper, 2016). Using a nutrient to stimulate the natural GH release from the anterior pituitary to increase blood GH 
concentrations compared with the discontinued recombinant bST product allows dairy producers to maintain production efficiency to feed the growing population economically.

Previously, we hypothesized (Hultquist and Casper, 2016) that Val would be metabolized by rumen microbes to isobutyric acid through ruminal microbial oxidative deamination and decarboxylation (Rosener and Uhlenhopp, 1987). Isobutyric acid would then be absorbed across the rumen wall into the bloodstream, increasing blood concentrations that would stimulate additional GH release from the pituitary gland (Liu et al., 2009), followed by enhanced milk production through the GH-IGF-1 axis. Although rumen fluid concentrations of isobutyrate did increase with increased Val supplementation, blood GH and IGF-1 concentrations were similar to those of cows fed without supplemental Val, leading us to speculate that another mechanism must be responsible for the increased milk production (Hultquist and Casper, 2016). The current study was undertaken to evaluate whether the thyroid hormones thyroxine (T4) and triiodothyronine (T3), which are important for basal metabolism and have resulted in increased milk production in cows fed iodinated casein (Van Landingham et al., 1944; Thomas et al., 1957), may be involved.

The lactational responses were previously published (Hultquist and Casper, 2016); briefly, 8 multiparous late-lactating Holstein dairy cows housed in freestalls at the South Dakota State University Dairy Research and Training Facility (Brookings) were randomly assigned to 1 of 4 treatments using a replicated $4 \times 4$ Latin square design having 21-d periods with $7 \mathrm{~d}$ for dietary adaptation and $14 \mathrm{~d}$ for data collection. Treatments were (1) control (no injection of recombinant bST or Val supplementation; CON); (2) a single injection of 14-d slow-release recombinant bST (Posilac, Elanco Animal Health, Greenfield, IN) given on d 1 of wk 2 of each period subcutaneously to either the right or left side of the tailhead (rbST); (3) Val (L-valine, Ajinomoto North America Inc., Fort Lee, NJ) fed at $40 \mathrm{~g} /$ cow per day (V40); and (4) Val fed at $80 \mathrm{~g} / \mathrm{cow}$ per day (V80). Cows were fed a TMR once a day consisting of $55 \%$ forage $(60 \%$ corn silage and $40 \%$ alfalfa haylage from the 2013 crop season) and $45 \%$ grain on a DM basis with a distillers dried grains carrier included at the rate of $113.4 \mathrm{~g} / \mathrm{cow}$ per day that contained no Val or Val added at the designated amounts. A coccygeal artery sample was collected using Vacutainer tubes containing $\mathrm{K}_{2}$-EDTA (Becton Dickinson Vacutainer Systems, Rutherford, NJ) twice weekly during wk 2 and 3 of each period $3 \mathrm{~h}$ after feeding. All blood samples were collected and immediately stored on ice until transported to the laboratory and centrifuged at $2,000 \times g$ for 20 min at $8^{\circ} \mathrm{C}$ (CR412 centrifuge; Jouan Inc., Winchester, VA) to separate plasma. After separation, plasma was stored in 5 -mL tubes at $-20^{\circ} \mathrm{C}$. These samples were then analyzed for T4 and T3 concentrations. Plasma concentrations of $\mathrm{T} 4$ were determined in duplicate using the $\mathrm{T} 4$ monoclonal solid-phase radioimmunoassay (\#06B-254030; MP Biomedicals, Solon, OH) according to the manufacturer's instructions. The interassay coefficient of variation (CV) was $14.0 \%$ and intraassay CV was $9.0 \%$. Sensitivity of the assay was $0.63 \mu \mathrm{g} /$ dL. Inhibition curves of plasma ranging from 10 to 25 $\mu \mathrm{L}$ were parallel to standard curves. Plasma concentrations of T3 were determined in duplicate using the T3 solid phase component system (\#06B-254216; MP Biomedicals) according to the manufacturer's instructions. Interassay $\mathrm{CV}$ was $9.6 \%$ and intraassay $\mathrm{CV}$ was $6.4 \%$. Sensitivity of the assay was $5.16 \mathrm{ng} / \mathrm{dL}$. Inhibition curves of plasma ranging from 25 to $100 \mu \mathrm{L}$ were parallel to standard curves.

All data were subjected to least squares ANOVA for a replicated $4 \times 4$ Latin square design (Steele and Torrie, 1980) using PROC MIXED of SAS (version 9.4, SAS Institute Inc., Cary, NC). The model included square, period within square, cow within square, treatment, day, and the interaction of treatment by day with day as a repeated-measures ANOVA. Significant differences were declared when $P<0.05$.

Injection of recombinant bST or feeding Val at 40 and $80 \mathrm{~g} / \mathrm{cow}$ per day to late-lactation dairy cows increased $(P<0.05)$ plasma T4 and T3 concentrations compared with cows fed CON (Table 1), which corresponds with the increased milk production for cows on treatments rbST, V40, and V80 reported in our previous paper (Hultquist and Casper, 2016). Cows fed V40 demonstrated the greatest $(P<0.05)$ T3 concentrations compared with cows receiving the other treatments. The thyroid gland of the lactating dairy cow is responsible for regulating basal metabolic rate (McGuffey, 2017); thus, increased release of $\mathrm{T} 4$ and $\mathrm{T} 3$ would increase basal metabolic rate. Increasing basal metabolic rate results in an increase in mammary blood flow, thereby delivering more nutrients to the mammary gland for milk synthesis and production. Davis et al. (1984) reported similar results, noting an increase in mammary blood flow with administration of GH and T4. This mechanism would be comparable to that of recombinant bST increasing milk production by increasing mammary blood flow.

A plausible mechanism for Val feeding to increase milk production is that Val is ruminally deaminated and decarboxylated by ruminal microbial organisms to isobutyric acid. This isobutyric acid is absorbed across the ruminal wall, thereby increasing blood isobutyrate concentrations that reach the hypothalamic-pituitary- 
Table 1. Plasma thyroxine (T4) and triiodothyronine (T3) concentrations

\begin{tabular}{|c|c|c|c|c|c|}
\hline \multirow[b]{2}{*}{ Measurement } & \multicolumn{4}{|c|}{ Treatment $^{1}$} & \multirow[b]{2}{*}{$\mathrm{SE}$} \\
\hline & $\mathrm{CON}$ & rbST & V40 & V80 & \\
\hline $\mathrm{T} 4, \mu \mathrm{g} / \mathrm{dL}$ & $3.28^{\mathrm{b}}$ & $3.90^{\mathrm{a}}$ & $3.98^{\mathrm{a}}$ & $3.87^{\mathrm{a}}$ & 0.14 \\
\hline $\mathrm{T} 3, \mathrm{ng} / \mathrm{dL}$ & $125.7^{\mathrm{c}}$ & $140.7^{\mathrm{b}}$ & $148.8^{\mathrm{a}}$ & $139.7^{\mathrm{b}}$ & 2.18 \\
\hline
\end{tabular}

thyroid axis, which stimulate the release of T4 and T3, leading to an increase in basal metabolic rate, which increases mammary blood flow, thereby providing more nutrients to the mammary gland for additional milk synthesis and yield. This mechanism needs further testing and evaluation because, to our knowledge, no studies have yet been conducted to evaluate the influence of isobutyric acid on thyroid hormonal release. It is known that GH secretion decreases thyrotropin secretion but increases the peripheral conversion of $\mathrm{T} 4$ to the more active T3 form (Jorgensen et al., 1989; Wyatt et al., 1998; Hilczer, 2015). In addition, thyroid hormones can regulate GH secretion by acting on the hypothalamus, pituitary gland, or both, which may explain the lack of a GH response in our previous study (Hultquist and Casper, 2016) compared with the literature (Liu et al., 2009).

In conclusion, feeding rumen-degradable Val increased plasma T4 and T3 concentrations, which could explain the increased milk production and provides a plausible mechanism for further testing and evaluation.

\section{ACKNOWLEDGMENTS}

The authors express appreciation to Ajinomoto North America Inc. (Fort Lee, NJ) for providing funding for the analysis of T4 and T3.

\section{REFERENCES}

Davis, S. L., K. L. Hossner, and D. L. Ohlson. 1984. Endocrine regulation of growth in ruminants. Manipulation of Growth in Farm Animals. Current Topics in Veterinary Medicine and Animal Science. Vol 26. Springer, Dordrecht, the Netherlands. https://doi.org/10 .1007/978-94-010-9482-5_18

Hilczer, M. 2015. Whether the administration of thyroid hormones may play a role in the treatment of short stature? Thyroid Res. 8(Suppl. 1):A10.

Hultquist, K. M., and D. P. Casper. 2016. Effects of feeding rumen-degradable valine on milk production in late-lactating dairy cows. J. Dairy Sci. 99:1201-1215. https://doi.org/10.3168/jds.2015-10197.

Jorgensen, J. O. L., S. A. Pedersen, P. Laurberg, J. Weeke, N. E. Skakkebaek, and J. S. Christiansen. 1989. Effects of growth hormone therapy on thyroid function of growth hormone-deficient adults with and without concomitant thyroxine-substituted central hypo- thyroidism. J. Clin. Endocrinol. Metab. 69:1127-1132. https://doi .org/10.1210/jcem-69-6-1127.

Kung, L., Jr., and L. M. Rode. 1996. Amino acid metabolism in ruminants. Anim. Feed Sci. Technol. 59:167-172.

Liu, Q., C. Wang, W. Z. Yang, B. Zhang, X. M. Yang, D. C. He, P. Zhang, K. H. Dong, and Y. X. Huang. 2009. Effects of isobutyrate on rumen fermentation, lactation performance and plasma characteristics in dairy cows. Anim. Feed Sci. Technol. 154:58-67. https: //doi.org/10.1016/j.anifeedsci.2009.08.001.

McGuffey, R. K. 2017. A 100-year review: Metabolic modifiers in dairy cattle nutrition. J. Dairy Sci. 100:10113-10142. https://doi.org/10 .3168/jds.2017-12987.

National Center for Biotechnology Information. 2015. Isobutyric acid. Accessed Apr. 25, 2015. http://pubchem.ncbi.nlm.nih.gov/ compound/isobutyric_acid\#section=Top.

National Research Council. 1994. Metabolic modifiers: Effects on the nutrient requirements of food-producing animals. Natl. Acad. Press, Washington, DC.

Papas, A. M., S. R. Ames, R. M. Cook, C. J. Sniffen, C. E. Polan, and L. Chase. 1984. Production responses of dairy cows fed diets supplemented with ammonium salts of iso C-4 and C-5 acids. J. Dairy Sci. 67:276-293. https://doi.org/10.3168/jds.S0022 $-0302(84) 81300-4$

Peirce-Sandner, S. B., A. M. Papas, J. A. Rogers, T. F. Sweeney, K. A. Cummins, H. R. Conrad, and L. D. Muller. 1985. Supplementation of dairy cows diets with ammonium salts of volatile fatty acids. J. Dairy Sci. 68:2895-2907. https://doi.org/10.3168/jds.S0022 $-0302(85) 81183-8$.

Rosener, D. L., and E. K. Uhlenhopp. 1987. Isoacids-An overview. Iowa State Univ. Vet. 49:15-20.

Steele, R. G. D., and J. H. Torrie. 1980. Principles and Procedures of Statistics. 2nd ed. McGraw-Hill Book Co., New York, NY.

Thomas, J. W., D. V. Kopland, E. A. Keyes, and L. A. Moore. 1957. A study of the short-term use of iodinated casein for milk production. J. Dairy Sci. 40:128-141. https://doi.org/10.3168/jds.S0022 -0302(57)94453-3.

Van Landingham, A. H., H. O. Henderson, and C. E. Weakley Jr.. 1944. The effect of iodinated casein (protamine) on milk and butterfat production and on the ascorbic acid content of the milk. J. Dairy Sci. 27:385-396. https://doi.org/10.3168/jds.S0022 -0302(44)92613-5.

Wyatt, D. T., N. Gesundheit, and B. Sherman. 1998. Changes in thyroid hormone levels during growth hormone therapy in initially euthyroid patients: Lack of need for thyroxine supplementation. J. Clin. Endocrinol. Metab. 83:3493-3497. https://doi.org/10.1210/ jcem.83.10.5202.

Yoder, P. 2015. Landscape of formulation platforms. Mid-South Nutrition Conf., Grapevine, TX. https://doi.org/10.13140/RG.2.1.3297 .7045 .

Zanton, G. I., G. R. Bowman, M. Vazquez-Anon, and L. M. Rode. 2014. Meta-analysis of lactation performance in dairy cows receiving supplemental dietary methionine sources or postruminal infusion of methionine. J. Dairy Sci. 97:7085-7101. https://doi.org/10 $.3168 /$ jds.2014-8220. 